\title{
A Rapid Attenuation of Muscarinic Agonist Stimulated Phosphoinositide Hydrolysis Precedes Receptor Sequestration in Human SH-SY-5Y Neuroblastoma Cells*
}

\author{
Stephen K. Fisher, ${ }^{1,2,3}$ Diana M. Slowiejko, ${ }^{1,2}$ and Edward L. McEwen ${ }^{1}$
}

(Accepted July 28, 1993)

\begin{abstract}
Agonist occupancy of muscarinic cholinergic receptors in human SH-SY-5Y neuroblastoma cells elicited two kinetically distinct phases of phosphoinositide hydrolysis when monitored by either an increased mass of inositol 1,4,5-trisphosphate, or the accumulation of a total inositol phosphate fraction. Within $5 \mathrm{~s}$ of the addition of the muscarinic agonist, oxotremorine- $\mathrm{M}$, the phosphoinositide pool was hydrolyzed at a maximal rate of $9.5 \% / \mathrm{min}$. This initial phase of phosphoinositide hydrolysis was short-lived $\left(t_{1 / 2}=14 \mathrm{~s}\right)$ and after $60 \mathrm{~s}$ of agonist exposure, the rate of inositol lipid breakdown had declined to a steady state level of $3.4 \% / \mathrm{min}$ which was then maintained for at least 5-10 min. This rapid, but partial, attenuation of muscarinic receptor stimulated phosphoinositide hydrolysis occurred prior to the agonist-induced internalization of muscarinic receptors.
\end{abstract}

KEY WORDS: Muscarinic cholinergic receptor; phosphoinositide hydrolysis; inositol 1,4,5-trisphosphate; SH-SY-5Y neuroblastoma; desensitization.

\section{INTRODUCTION}

Relatively little is known of the molecular mechanisms that underlie the regulation of inositol lipid turnover in the central nervous system despite the fact that more pharmacologically distinct receptors operate via phosphoinositide (PPI) hydrolysis than through any other known signal transduction mechanism. Our recent studies of the regulation of PPI turnover have utilized two human neuroblastoma cell lines (SK-N-SH and its neuroblast subclone, SH-SY-5Y), both of which possess PPIlinked muscarinic cholinergic receptors (mAChRs) at densities comparable to those found in the central ner-

\footnotetext{
${ }^{1}$ Neuroscience Laboratory

2 Department of Pharmacology University of Michigan Ann Arbor, MI 48104-1687

${ }^{3}$ Address reprint requests to: Dr. Stephen K. Fisher, Neuroscience Laboratory, University of Michigan, 1103 E. Huron St. Ann Arbor, MI 48104-1687.

* Special issue dedicated to Dr. Bernard W. Agranoff.
}

vous system. In these cells $(1,2)$ and in other neural tissues (3-6), mAChR-stimulated PPI turnover, as monitored by a release of radiolabeled inositol phosphates, appears not to readily desensitize, i.e., it proceeds continuously for an extended time period (30-60 min). The eventual loss of functional response is triggered by an agonist-induced sequestration and down-regulation of cell surface mAChRs $(1,7)$.

To evaluate further the apparent refractoriness of mAChR-stimulated PPI hydrolysis to desensitization, in the present study we have examined the rapid kinetics of PPI hydrolysis in SH-SY-5Y neuroblastoma, a cellline which possesses a relatively homogeneous population of mAChRs of the $m_{3}$ subtype $(2,8,9)$. We report

\footnotetext{
Abbreviations: $\mathrm{I}(1,4,5) \mathrm{P}_{3}$, inositol 1,4,5-trisphosphate; IP, total inositol phosphate fraction; IPL, total inositol lipid fraction; $m A C h R$, muscarinic acetylcholine receptor; NMS, N-methylscopolamine; OxoM, oxotremorine-M; PI, phosphatidylinositol; PIP, phosphatidylinositol 4-phosphate; $\mathrm{PIP}_{2}$, phosphatidylinositol 4,5-bisphosphate; PPI, phosphoinositide; QNB, quinuclidinyl benzilate.
} 
here that activation of mAChRs on these ceils elicits two kinetically distinct phases of PPI hydrolysis. A rapid initial phase of $\mathrm{mAChR}$-stimulated inositol lipid breakdown, which was previously unrecognized, occurs during the first few seconds of agonist exposure and results in the hydrolysis of the inositol lipid pool at a maximal rate of $9.5 \% / \mathrm{min}$. This initial component of stimulated PPI hydrolysis is followed by a slower but more sustained phase of inositol lipid breakdown which proceeds at a rate of approximately $3.4 \% / \mathrm{min}$. The rapid, but partial, attenuation of PPI hydrolysis in response to $\mathrm{mAChR}$ activation occurs prior to $\mathrm{mAChR}$ internalization and may represent an important early adaptive response to chronic agonist stimulation.

\section{EXPERIMENTAL PROCEDURE}

Materials. SH-SY-5Y neuroblastoma cells were obtained from Dr. June Biedler, Sloan Kettering Institute, New York. The source of SK-N-SH cells was as previously described (10). myo- $\left[2-{ }^{3} \mathrm{H}\right]$ Inositol (15 Ci/mmol) was obtained from American Radiolabeled Chemicals, St. Louis, MO. N-[3 $\left.{ }^{3} \mathrm{H}\right]$ Methylscopolamine ([3 H]NMS: $\left.79.5 \mathrm{Cz} / \mathrm{mmol}\right)$, $\left[{ }^{3} \mathrm{H}\right.$ qquinuclidinyl benzilate (QNB: $45.4 \mathrm{Ci} / \mathrm{mmol}$ ) and [ $\left.{ }^{3} \mathrm{H}\right]$ oxotremorine$\left.\mathrm{M}\left({ }^{3} \mathrm{H}\right] \mathrm{Oxo}-\mathrm{M}: 87.5 \mathrm{Ci} / \mathrm{mmol}\right)$ were from New England Nuclear, Boston, MA. Oxotremorine-M was purchased from Research Biochemicals, Inc., Natick, MA. Atropine was obtained from Sigma Chemical Co., St. Louis, MO. Tissue culture supplies were obtained from Corning Glass Works, Corning, NY. Powdered Dulbecco's modified Eagle's medium and fetal bovine serum were purchased from GIBCO, Grand Island, NY. Dowex-1 (100-200 mesh, $\times 8$ in the formate form) was obtained from Bio-Rad Laboratories, Mclville, NY.

Cell Culture Conditions. Human SH-SY-5Y (passages 67-94) or SK-N-SH cells (passage number unknown) were grown in tissuc culture flasks $\left(75 \mathrm{~cm}^{2} / 250 \mathrm{mi}\right)$ in $20 \mathrm{mis}$ of Dulbecco's modified Eagle's medium supplemented with $10 \%$ (by volume) fetal calf serum (Medium I). Cells were grown for $10-20$ days at $37^{\circ}$ in an atmosphere consisting of $10 \% \mathrm{CO}_{2}$ and $90 \%$ humidified air. Cells were detached by aspirating Medium I and isolating the cells after incubation with a modified Pucks $\mathrm{D}_{1}$ solution (10).

Measurement of Phosphoinositide Tumover. Inositol 1,4,5-trisphosphate $\left[\mathrm{I}(1,4,5) \mathrm{P}_{3}\right]$ mass was measured by a commercially available radioreccptor binding assay kit (Dupont-NEN) (11). For radiolabeling studies, SH-SY-5Y or SK-N-SH cells were allowed to prelabel for 3 days in Dulbecco's modified Eagle's medium $10 \%$ fetal calf serum containing $10 \mu \mathrm{Ci} / \mathrm{ml}\left[{ }^{3} \mathrm{H}\right]$ inositol. Isotopic equilibrium labeling of inositol lipids in both cell lines was attained within a 48 $\mathrm{h}$ labeling period. Cells were detached and washed once in Buffer $\mathrm{A}$ $\left(142 \mathrm{mM} \mathrm{NaCl}, 5.6 \mathrm{mM} \mathrm{KCl}, 2.2 \mathrm{mM} \mathrm{CaCl}_{2}, 3.6 \mathrm{mM} \mathrm{NaHCO}, 1\right.$ $\mathrm{mM} \mathrm{MgCl} 2,5.6 \mathrm{mM}$ D-glucose, $30 \mathrm{mM}$ sodium HEPES buffer, $\mathrm{pH}$ 7.4). Cells were then resuspended in buffer $\mathrm{A}$ containing LiCl (final concentration, $20 \mathrm{mM}$ ) and preincubated for $2 \mathrm{~min}$ at $37^{\circ} \mathrm{C}$ prior to the addition of either $1 \mathrm{mM}$ Oxo-M and/or $50 \mu \mathrm{M}$ atropine (final volume, $0.5 \mathrm{ml}$ ). Both the accumulation of $\left[{ }^{3} \mathrm{H}\right]$ inositol phosphates (IP) in the presence of $\mathrm{Li}^{+}$, and incorporation of radiolabel into a total inositol lipid fraction (IPL) at time zcro, were monitored as previously described (1). Radiolabeled phospholipids [phosphatidylinositol 4,5bisphosphate $\left(\mathrm{PIP}_{2}\right)$; phosphatidylinositol 4-phosphate (PIP) and phos- phatidylinositol (PI)] were extracted from the trichloroacetic acid precipitates, separated by thin layer chromatography and quantitated as previously described (12). Râtes of PPI hydrolysis were calculated as $(\triangle \mathrm{IP} / \mathrm{IPL}) \times 100 \%$, where $\triangle \mathrm{IP}=\left[{ }^{3} \mathrm{H}\right] \mathrm{IP}$ released $/ \mathrm{min}$ at specified time points. Protein was determined by the method of Geiger and Bessman (13). Students $t$ tests were used to evaluate the statistical differences of the means of paired or unpaired sets of data. The curves for the rate of $\left[{ }^{3} \mathrm{H}\right] \mathrm{P}$ accumulation and breakdown of $\left[{ }^{3} \mathrm{H}\right] \mathrm{PIP}{ }_{2}$ were fitted by a non-linear least squares regression analysis assuming an exponential decay (GraphPad InPlot). The $t_{1 / 2}$ values quoted reflect the time required for half-maximal reduction in the initial rate of stimulated $\left[{ }^{3} \mathrm{H}\right] \mathrm{IP}$ formation (Fig- $2 \mathrm{~B}$ ) or half-maximal breakdown of tadiolabcled $\mathrm{PIP}_{2}$ initially present (Fig. 3 ).

Radioligand Binding. SH-SY-5Y cells were incubated for the times indicated in the absence or presence of $1 \mathrm{mM}$ Oxo-M at $37^{\circ} \mathrm{C}$ (final $\mathrm{vol}=5 \mathrm{ml}$ ). Reactions were terminated by the addition of $30 \mathrm{ml}$ icecold Buffer A, cells centrifuged at $300 \mathrm{~g}$ for $3 \mathrm{~min}$ and resuspended in Buffer A. Parallel experiments conducted in the presence of $1 \mu \mathrm{Ci}$ of $\left[{ }^{3} \mathrm{H}\right] \mathrm{OxO}-\mathrm{M}$ indicated that $>99 \%$ of the agonist was removed by this procedure. The binding of $\left[{ }^{3} \mathrm{H}\right] \mathrm{NMS}$ or $\left[{ }^{3} \mathrm{H}\right] \mathrm{QNB}$ to $\mathrm{mAChRs}$ on intact SH-SY-5Y cells was then measured as previously described for SK-N-SH cells (14). Cells were incubated overnight with $\left[{ }^{3} \mathrm{H}\right] \mathrm{NMS}$ at $4^{\circ} \mathrm{C}$, or for $90 \mathrm{~min}$ at $37^{\circ} \mathrm{C}$ for $\left[{ }^{3} \mathrm{H}\right] \mathrm{QNB}$ binding.

\section{RESULTS}

$I(1,4,5) P_{3}$ Mass Measurements. The addition of 1 $\mathrm{mM}$ Oxo-M to SH-SY-5Y cells resulted in a rapid, but transient, 4-5 fold increase in the mass of $\mathrm{I}(1,4,5) \mathrm{P}_{3}$ within 5-10s. By 60 s the net accumulation of $\mathrm{I}(1,4,5) \mathrm{P}_{3}$ had declined to approximately $35 \%$ of that attained during the first few seconds of agonist addition. Thereafter, the amount of $\mathrm{I}(1,4,5) \mathrm{P}_{3}$ remained constant for up to 5 min of agonist exposure (Fig. 1).

Accumulation of a Total Inositol Phosphate Fraction. Because the rapid decline in $\mathrm{I}(1,4,5) \mathrm{P}_{3}$ mass could reflect a diminished rate of synthesis or an increased metabolism, we also monitored PPI hydrolysis by means of the accumulation of a total inositol phosphate fraction (IP) in the presence of $\mathrm{Li}^{+}$(1). Under these conditions, the addition of $1 \mathrm{mM}$ Oxo-M to SH-SY-5Y cells that had been prelabeled to isotopic equilibrium with $\left[{ }^{3} \mathrm{H}\right]$ inositol resulted in a rapid release of $\left[{ }^{3} \mathrm{H}\right] \mathrm{IP}$, the time-course of which was curvilinear over the initial $60 \mathrm{~s}$ following agonist addition (Fig. 2A). However after this time, Oxo-M-stimulated [ $\left.{ }^{3} \mathrm{H}\right] \mathrm{IP}$ formation proceeded linearly for the next $9 \mathrm{~min}$ (Fig. 2A-inset). When atropine $(50 \mu \mathrm{M})$ was added to cells that had been incubated in the presence of Oxo-M for $3 \mathrm{~min}$, the subsequent [ $\left.{ }^{3} \mathrm{H}\right] \mathrm{IP}$ formation was blocked, but accumulated radiolabel did not decline over the next 30 min indicating that $\mathrm{Li}^{+}$fully inhibited the degradation of $\left[{ }^{3} \mathrm{H}\right] \mathrm{IP}$ in these cells (data not shown). In a series of experiments, $\left[{ }^{3} \mathrm{H}\right] \mathrm{IP}$ formation was monitored as a function of time and results ex- 


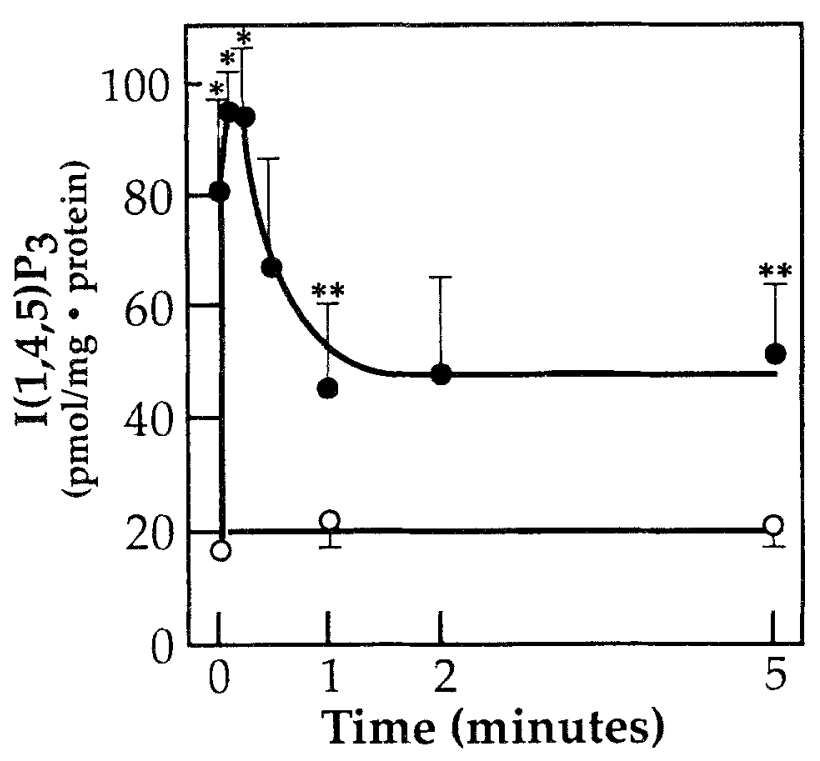

Fig. 1. Kinctics of mAChR-stimulated $\mathrm{I}(1,4,5) \mathrm{P}_{3}$ formation. Cells (approximately $1 \mathrm{mg}$ of protein) were incubated in the presence of $1 \mathrm{mM}$ Oxo-M ( ) or buffer A (O) for the times indicated. $\mathrm{LiCl}(20 \mathrm{mM})$ was routinely included to allow a direct comparison with $\left[{ }^{3} \mathrm{H}\right] \mathrm{IP}$ data. Values shown are means \pm SEM for four separate experiments. Although interexpcrimental variation was observed in terms of the absolute increase in the mass of $\mathrm{I}(1,4,5) \mathrm{P}_{3}$ formed in the presence of Oxo-M, the kinetic profile shown was consistently obtained. Where error bars are not shown, the SEM fell within the symbol. *Different from values obtained at $60 \mathrm{~s}, \mathrm{p}<0.05$. ${ }^{* *}$ Different from values obtained with buffer $\mathrm{A}, \mathrm{p}<0.05$ (matched-pair analysis).

pressed relative to radioactivity present in the inositol lipid fraction. From the rate of [ $\left.{ }^{3} \mathrm{H}\right] \mathrm{IP}$ formation obtained after $5 \mathrm{~s}$ of agonist addition, a PPI breakdown rate of $9.5 \% / \mathrm{min}$ was calculated. After $60 \mathrm{~s}$ of agonist addition, the rate of stimulated PPI hydrolysis had declined to $3.4 \% / \mathrm{min}\left(\mathrm{t}_{1 / 2}=14 \mathrm{~s}\right)$, and thereafter remained constant (Fig. 2B). Under basal conditions (absence of agonist), the rate of PPI hydrolysis was $0.06 \% / \mathrm{min}$. Additional experiments were also performed with the parent cell line, SK-N-SH, which we have previously used for studies of mAChR regulation $(1,7)$. As observed for SH-SY$5 Y$ cells, the rate of PPI hydrolysis observed after $5 \mathrm{~s}$ of agonist addition was significantly greater than that obtained after $60 \mathrm{~s}(13.0 \pm 4.3$ vs $5.0 \pm 1.5 \% / \mathrm{min}, \mathrm{p}<$ $0.05, \mathrm{n}=4)$.

Inositol Lipid Breakdown. The addition of $1 \mathrm{mM}$ Oxo-M to SH-SY-5Y cells that had been labeled to isotopic equilibrium with $\left[{ }^{3} \mathrm{H}\right]$ inositol also resulted in a rapid breakdown of $\left[{ }^{3} \mathrm{H}\right] \mathrm{PIP}_{2}\left(\mathrm{t}_{1 / 2}=12 \mathrm{~s}\right)$. Sixty seconds after agonist addition, however, a new steady state of $\left[{ }^{3} \mathrm{H}\right] \mathrm{PIP}_{2}$ label was achieved and maintained for up to 5-10 min (33\% of that observed at zero time; Fig. 3 ). The net loss of radiolabel from PIP (33\%) and PI (7\%) was less marked and occurred more slowly than that observed for $\mathrm{PIP}_{2}$. The maintenance of radiolabel in PI following continuous agonist exposure may reflect its resynthesis and the utilization of residual free $\left[{ }^{3} \mathrm{H}\right]$ inositol present in the cells. Because the majority (94\%) of label present in the inositol lipids was recovered in the relatively stable PI fraction, radioactivity associated with the total inositol lipid fraction was reduced by $<10 \%$ during the course of the incubations.

$m A C h R$ Sequestration in SH-SY-5Y Cells. To determine whether the rapid attenuation of PPI hydrolysis was related to sequestration of cell surface mAChRs (7), the time course of Oxo-M-mediated loss of $\left.{ }^{3} \mathrm{H}\right] \mathrm{NMS}$ sites was monitored. No significant loss of $\left[{ }^{3} \mathrm{H}\right] \mathrm{NMS}$ sites occurred before $5 \mathrm{~min}$ of exposure of the cells to the agonist whereas a maximum sequestration ( $47 \pm$ $2 \%, \mathrm{n}=3$ ) was observed after $30 \mathrm{~min}$ (Fig. 4). Little or no loss of total $\mathrm{mAChRs}$ (as revealed by measurement of $\left[{ }^{3} \mathrm{H}\right] \mathrm{QNB}$ binding sites) occurred at any of the time points examined $(8 \pm 5 \%$ at $30 \mathrm{~min}, \mathrm{n}=3$ ).

\section{DISCUSSION}

The principal conclusion to emerge from the present study is that two kinetically distinct phases of PPI hydrolysis result from agonist occupancy of mAChRs in human SK-N-SH and SH-SY-5Y neuroblastoma cells, i.e., an initial rapid phase that, presumably due to its transient nature, was not previously identified $(1,2)$ and a secondary slower but sustained rate of inositol lipid hydrolysis. The biphasic kinetics of mAChR-stimulated PPI hydrolysis were evident from measurement of both $\mathrm{I}(1,4,5) \mathrm{P}_{3}$ mass, and the rate of accumulation of a total inositol phosphate fraction. However, the transient nature of the 4-5 fold increase in $\mathrm{I}(1,4,5) \mathrm{P}_{3}$ mass observed within $5-15 \mathrm{~s}$ of muscarinic agonist addition in this and a previous study (11) could reflect either a subsequent reduction in the rate of $\mathrm{I}(1,4,5) \mathrm{P}_{3}$ synthesis, or an increased rate of its metabolism. In this context, previous studies with non-neural cells have indicated that agoniststimulated $\left[{ }^{3} \mathrm{H}\right] \mathrm{IP}$ formation can proceed steadily under conditions in which little or no net formation of $\mathrm{I}(1,4,5) \mathrm{P}_{3}$ is detected $(15,16)$. In SH-SY-5Y cells, attenuation of the rate of mAChR-stimulated PPI hydrolysis was more unequivocally demonstrated by the rapid reduction in the rate of $\left[{ }^{3} \mathrm{H}\right] \mathrm{IP}$ formation (Fig. $2 \mathrm{~A}, \mathrm{~B}$ ), since this measurement is independent of the further metabolism of $\mathrm{I}(1,4,5) \mathrm{P}_{3}$ and monitors the continuous accumulation of products (1). The rate of Oxo-M-stimulated $\left[{ }^{3} \mathrm{H}\right] \mathrm{IP}$ accumulation monitored after $5-15 \mathrm{~s}$ of agonist exposure 

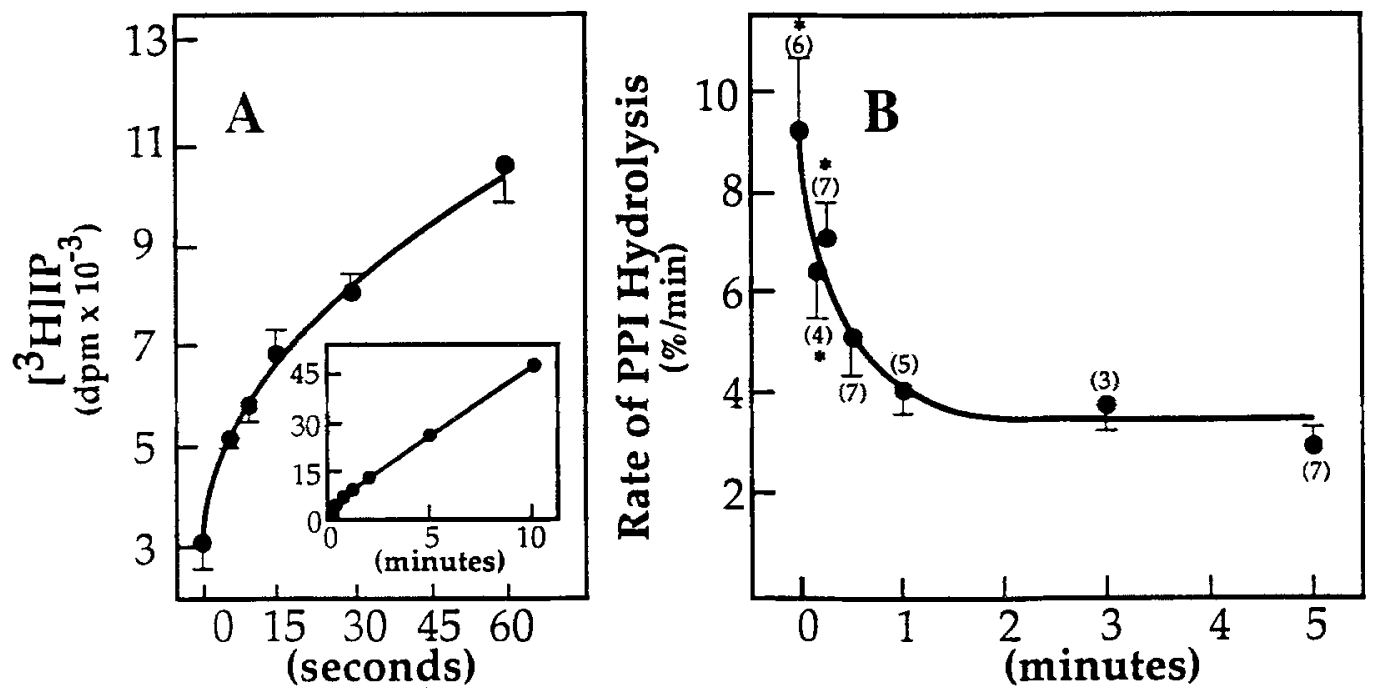

Time

Fig. 2. Kinetics of mAChR-stimulated [ $\left.{ }^{3} \mathrm{H}\right] \mathrm{IP}$ formation. (A): SH-SY-5Y cells labeled to isotopic equilibrium with [ $\left.{ }^{3} \mathrm{H}\right]$ inositol (approximately 1 mg of protein) were incubated with $1 \mathrm{mM}$ Oxo-M for the times indicated. Reactions were terminated by the addition of trichloroacetic acid and a total labeled inositol phosphate fraction isolated. Values shown are means \pm SEM for triplicate replicates from one of five experiments that gave similar results. Inset: stimulated inositol phosphate release in more extended incubations. Little or no increase in basal release of inositol phosphates occurred. (B) Rate of mAChR-stimulated PPI hydrolysis $(5 \mathrm{~s}-5 \mathrm{~min})$, calculated as $\left(\triangle\left[{ }^{3} \mathrm{H}\right] \mathrm{IP} / \mathrm{IPL}\right) \times 100 \%$, where $\Delta\left[{ }^{3} \mathrm{H}\right] \mathrm{IP}=\left[{ }^{3} \mathrm{H}\right] \mathrm{IP}$ released/ min at specified time points and IPL is radioactivity present in inositol lipids at time zero. Values shown are means \pm SEM for the number of separate experiments indicated in parentheses. The basal release of PPI hydrolysis was approximately $0.06 \% / m i n . ~{ }^{*}$ Different from the rate measured at $60 \mathrm{~s}, \mathrm{p}<0.05$

consistently exceeded that observed at 60 s or thereafter by $2-3$ fold. The similarities in the kinetics of the accumulation of both $\left[{ }^{3} \mathrm{H}\right] \mathrm{IP}$ and $\mathrm{I}(1,4,5) \mathrm{P}_{3}$ mass provide strong evidence that changes in the rate of $\mathrm{mAChR}$-stimulated PPI hydrolysis (rather than in the breakdown of $\left.\mathrm{I}(1,4,5) \mathrm{P}_{3}\right)$ account for the rapid attenuation of enhanced inositol lipid turnover in these cells. It should be noted that the time period in which the rate of mAChR-stimulated PPI hydrolysis is highest, i.e., approx. 5-10s after agonist addition, is also that time at which the receptormediated increases in intracellular $\mathrm{Ca}^{2+}(2,11,17)$ and release of inositol lipid-derived diacylglycerols (18) are also maximal.

Although evidence is currently lacking, the reduction in $\mathrm{m}_{3} \mathrm{mAChR}$-stimulated PPI hydrolysis in SH-SY$5 \mathrm{Y}$ cells could conceivably reflect a phosphorylation of the $m_{3}$ receptor (19), as has also been observed for the $m_{2}$ mAChR linked to adenylyl cyclase activity in heart (20). Alternatively, because the rate of PPI hydrolysis increases more than 150 -fold within $5 \mathrm{~s}$ of Oxo-M addition (0.06 to $9.5 \% / \mathrm{min}$, see Fig. 2B), depletion of the available $\mathrm{PIP}_{2}$ substrate may account for the subsequent reduction in the rate of inositol lipid breakdown. Although interpretation of changes in $\left[{ }^{3} \mathrm{H}\right] \mathrm{PIP}_{2}$ is compli- cated by the simultaneous occurrence of both lipid degradation and resynthesis, it is noteworthy that the $\mathrm{t}_{1 / 2}$ for Oxo-M-stimulated $\left[{ }^{3} \mathrm{H}\right] \mathrm{PIP}_{2}$ breakdown (12s) closely matched that obtained for the attenuation of the rapid phase of $\left[{ }^{3} \mathrm{H}\right] \mathrm{IP}$ formation (14s). $\mathrm{PIP}_{2}$, which is formed from the sequential phosphorylation of PI and PIP, is the primary substrate for PPI hydrolysis (12). However, it comprises only $2-3 \%$ of the total inositol lipid pool in SH-SY-5Y cells, and thus under conditions in which the latter is hydrolyzed at a rate of $9.5 \% / \mathrm{min}$, the entire $\mathrm{PIP}_{2}$ pool must be renewed every 13-19s. Under these conditions, the activities of PI- and PIP kinases may become rate-limiting and insufficient to replenish the $\mathrm{PIP}_{2}$ pool. An additional consideration is that agonist sensitive and -insensitive pools of inositol lipid may exist (21), in which case the turnover of the relevant pool of $\mathrm{PIP}_{2}$ may be even more rapid. In contrast, the resynthesis of $\left[{ }^{3} \mathrm{H}\right] \mathrm{PI}$ is maintained even under conditions in which inositol reutilization might be comprised, i.e., prolonged agonist administration in the presence of $\mathrm{Li}^{+}$(1). Thus, inositol availability appears not to be rate-limiting, a conclusion consistent with the reportedly high intracellular concentrations of inositol (approx. $6 \mathrm{mM}$ ) present in these neuroblastoma cells (22). Whatever the precise 


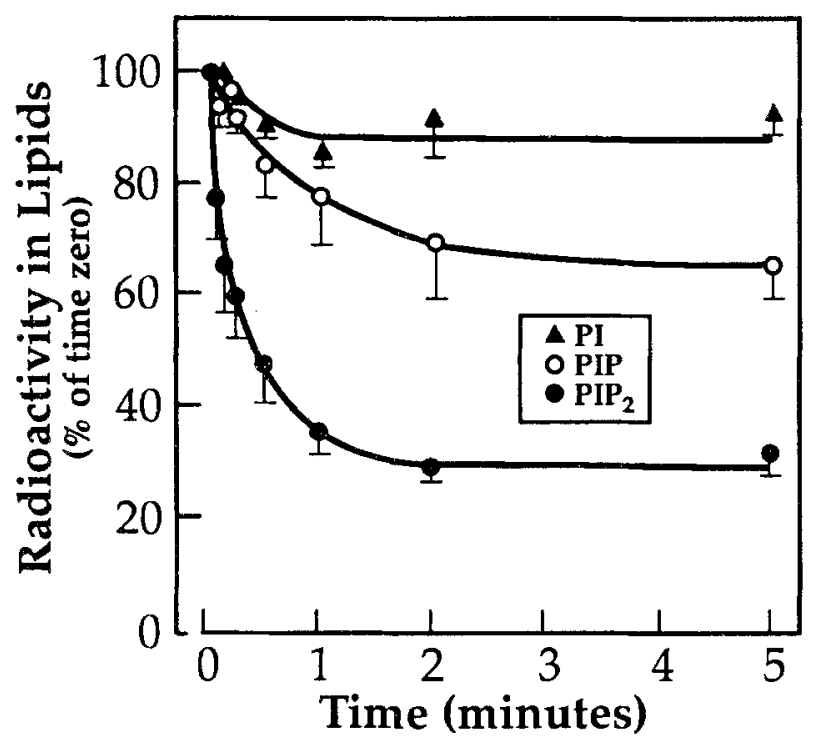

Fig. 3. Kinetics of inositol lipid hydrolysis. Cells labeled to isotopic equilibrium with $\left.{ }^{3} \mathrm{H}\right]$ inositol (approximately $1 \mathrm{mg}$ of protein) were incubated with $1 \mathrm{mM}$ Oxo-M for the times indicated. Reactions were terminated by the addition of trichloroacetic acid; phospholipids present in the precipitates were then extracted, separated by thin layer chromatography and quantitated following autoradiography. Values shown are means \pm SEM for 3-4 separate experiments. Little or no change in $\mathrm{PI}, \mathrm{PIP}$ and $\mathrm{PIP}_{2}$ radioactivity occurred under basal conditions. Of the radioactivity recovered in the inositol lipids, $94 \pm 1,4$ \pm 1 and $2 \pm 0 \%$ was recovered in $\mathrm{PI}, \mathrm{PIP}$ and $\mathrm{PIP}_{2}$, respectively. Incorporation of $\left[{ }^{3} \mathrm{H}\right]$ inositol into the lipid fraction was approximately $300,000 \mathrm{dpm} / \mathrm{mg}$ of protein.

mechanism for the attenuation of PPI hydrolysis, it appears unrelated to the internalization of mAChRs. Although the latter is the precursor of receptor down regulation and desensitization of stimulated PPI hydrolysis following long-term agonist exposure $(1,7)$, the rapid attenuation of PPI hydrolysis observed in the present study occurs prior to, and thus is independent of, the redistribution of cell surface mAChRs.

In summary, the present results indicate that the rate of muscarinic agonist-stimulated PPI hydrolysis in SHSY-5Y cells undergoes a rapid, but partial, attenuation. This change in $\mathrm{mAChR}$ responsiveness may represent an early adaptive phase in PPI-mediated signal transduction not previously recognized in these cells.

\section{ACKNOWLEDGMENTS}

The authors wish to thank Drs. Anne Heacock, John A. Williams and Richard Neubig for their helpful comments and Jo Ann Kelsch for preparation of the manuscript. This study was supported by NIMH MH 42652 and NIH NS 23831. Diana M. Slowicjko was supported by NIH Training Grant, GM 07767-10.

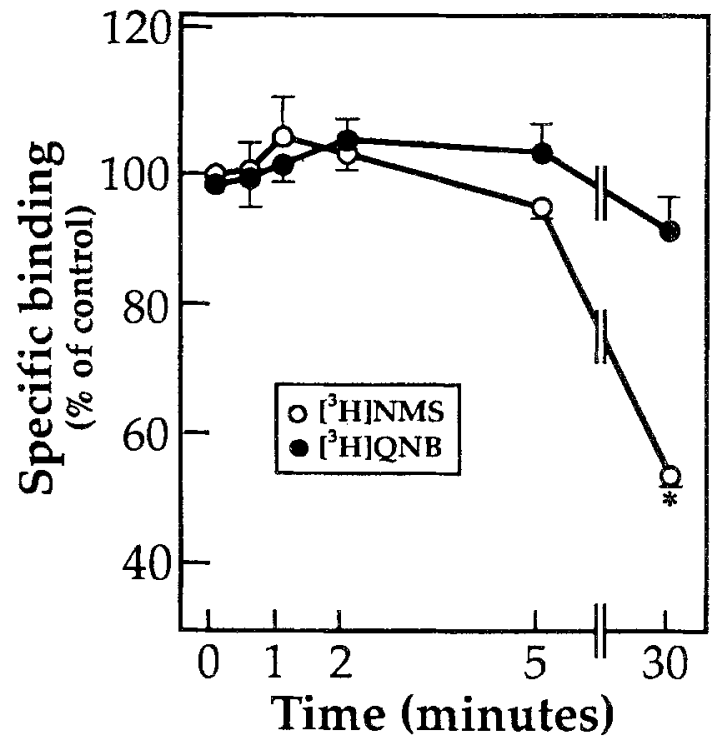

Fig. 4. Time-course of $\mathrm{mAChR}$ sequestration and down-regulation. Cells were incubated in the presence or absence of $1 \mathrm{mM}$ Oxo-M for the times indicated. Values shown are means \pm SEM for 3 separate experiments. In control cells, mAChR densities were $298 \pm 70$ and $319 \pm 51 \mathrm{fmol} / \mathrm{mg}$ protein when monitored by [ $\left.{ }^{3} \mathrm{H}\right] \mathrm{NMS}$ and $\left[{ }^{3} \mathrm{H}\right] \mathrm{QNB}$, respectively. ${ }^{*}$ Different from corresponding controls, $p<0.05$ (matchedpair analysis).

\section{REFERENCES}

1. Thompson, A. K., and Fisher, S. K. 1990. Relationship between agonist-induced muscarinic receptor loss and desensitization of stimulated phosphoinositide turnover in two neuroblastomas: methodological considerations. J. Pharmacol. Exp. Ther. 252:744 752.

2. Cioffi, C. L., and Fisher, S. K. 1990. Reduction of muscarinic receptor density and of guanine-nucleotide stimulated phosphoinositide hydrolysis in human SH-SY-5Y neuroblastoma cells following long-term treatment with 12-0-tetradecanoylphorbol-13acetate or mezerein, J. Neurochem. 54:1725-1734.

3. Masters, S. B., Quinn, M. T., and Brown, J. H. 1985. Agonistinduced desensitization of muscarinic receptor-mediated calcium efflux without concomitant desensitization of phosphoinositide hydrolysis. Mol. Pharmacol. 27:325-332.

4. Xu, J., and Chuang, D-M. 1987. Muscarinic acetylcholine receptor-mediated phosphoinositide tumover in cultured cerebellar granule cells: desensitization by receptor agonists. J. Pharmacol. Exp. Ther. 242:238-242.

5. Nakahata, N., and Harden, T. K. 1987. Regulation of inositol trisphosphate accumulation by muscarinic cholinergic and $\mathrm{H}_{1}$-histamine receptors on human astrocytoma cells. Biochem. J. 241:337344.

6. Lenox, R. H., Hendley, D., and Elis, J. 1988. Desensitization of muscarinic receptor-coupled phosphoinositide hydrolysis in rat hippocampus: comparisons with the $\alpha_{1}$-adrenergic response. J. Ncurochem. 50:558-564.

7. Thompson, A. K., and Fisher, S. K. 1991. Preferential coupling of cell surface muscarinic receptors to phosphoinositide hydrolysis in human neuroblastoma cells. J. Biol. Chem. 266:5004-5010.

8. Lambert, D. G., Ghataorre, A. S., and Nahorski, S. R. 1989. 
Muscarinic receptor binding characteristics of a human neuroblastoma SK-N-SH and its clones SH-SY-5Y and SH-EP1. Eur. J. Pharmacol. 165:71-77.

9. Wall, S. J., Yasuda, R. P., Li, M., and Wolfe, B. B. 1991. Development of an antiserum against $\mathrm{m}_{3}$ receptors in rat tissues and clonal cell lines. Mol. Pharmacol. 40:783-789.

10. Fisher, S. K., and Snider, R. M. 1987. Differential receptor occupancy requirements for muscarinic cholinergic stimulation of inositol lipid hydrolysis in brain and in neuroblastomas. Mol. Pharmacol, 32:81-90.

11. Lambert, D. G., and Nahorski, S. R. 1990. Muscarinic-receptormediated changes in intracellular $\mathrm{Ca}^{2+}$ and inositol 1,4,5-trisphosphate mass in a human neuroblastoma cell line, SH-SY5Y. Biochem. J. 265:555-562.

12. Fisher, S. K., Heacock, A. M., Seguin, E. B., and Agranoff, B. W. 1990. Polyphosphoinositides are the major source of inositol phosphates in carbamoylcholine-stimulated SK-N-SH neuroblastoma cells. Mol. Pharmacol. 38:54 63.

13. Geiger, P. J., and Bessman, S. P. 1972. Protein determination by Lowry's method in the presence of sulfhydryl reagents. Anal. Biochem. 49:467-474.

14. Fisher, S. K. 1988. Recognition of muscarinic cholinergic receptors in human SK-N-SH neuroblastoma cells by quaternary and tertiary ligands is dependent upon temperature, cell integrity and the presence of agonists. Mol. Pharmacol. 33:414-422.

15. Hepler, J. R., Earp, H. S., and Harden, T. K. 1988. Long-term phorbol ester treatment down-regulates protein kinase $\mathrm{C}$ and sensitizes the phosphoinositide signaling pathway to hormone and growth factor stimulation. J. Biol. Chem. 263:7610-7619.
16. Plevin, R., and Wakelam, M. J. O. 1992. Rapid desensitization of vasopressin-stimulated phosphatidylinositol 4,5-bisphosphate and phosphatidylcholine hydrolysis questions the role of these pathways in sustained diacylglycerol formation in A10 vascularsmooth-muscle cells. Biochem. J. 285:759-766.

17. Físher, S. K., Domask, L. M., and Roland, R. M. 1989. Muscarinic receptor regulation of cytoplasmic $\mathrm{Ca}^{2+}$ concentrations in human SK-N-SH neuroblastoma cells: $\mathrm{Ca}^{2+}$ requirements for phospholipase $\mathrm{C}$ activation. Mol. Pharmacol. 35:195-204.

18. Lee, C., Fisher, S. K., Agranoff, B. W., and Hajra, A. K. 1991. Quantitative analysis of molecular species of diacylglycerol and phosphatidate formed upon muscarinic receptor activation of human SK-N-SH neuroblastoma cells. I. Biol. Chem. 266:2283722846.

19. Tobin, A. B., and Nahorski, S. R. 1993. Rapid agonist-mediated phosphorylation of m3-muscarinic receptors revealed by immunoprecipitation. J. Biol. Chem. 268:9817-9823.

20. Kwatra, M. M., Leung, E., Maan, A. C., McMahon, K. K., Ptasienski, J., Green, R. D., and Hosey, M. M. 1987. Correlation of agonist-induced phosphorylation of chick heart muscarinic reccptors with receptor desensitization. J. Biol. Chem. 262:16314 16321.

21. Monaco, M. E., and Gershengorn, M. C. 1992. Subcellular organization of receptor-mediated phosphoinoisitide turnover. Endocrine Rev. 13:707-718.

22. Stubbs, E. B., Jr., and Agranoff, B. W. 1993. Lithium enhances muscarinic receptor-stimulated CDP-diacylglycerol formation in inositol-depleted SK-N-SH neuroblastoma cells. J. Neurochem. $60: 1292-1299$ 